\title{
Något ändå
}

\section{Av Bärbel Westphal, universitetsadjunkt i tyska}

Länk till presentation av Bärbel Westphal

\section{Något ändå}

Stumt förgår blomningens jubel och tjuskraft. Utan klagan böjer sig bladen, ger rum åt det nya liv som pockar på: en frukt skall alstras.

Sorgen växer, men ur djupet tar trädet beslutet att bidra med sitt inneboende liv.

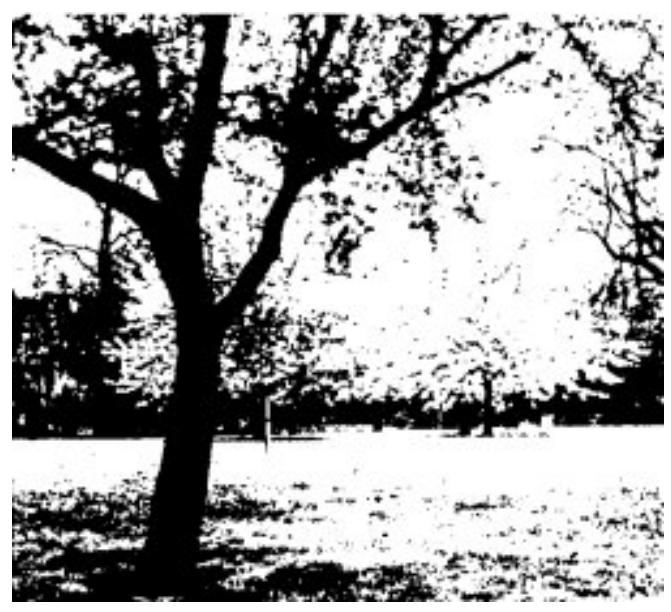

(C) text och foto Bärbel Westphal 